\title{
BACTERIAL AND PLANKTON COMMUNITIES IN MARICULTURE WATER SOURCES: A CASE STUDY IN NAMPU AND SEMBUKAN SEAWATERS, WONOGIRI, INDONESIA
}

\section{Yuni Puji Hastuti ${ }^{1 *}$, Yuli Siti Fatma ${ }^{2}$, Hardi Pitoyo $^{3}$, YUSLI WARDiaTnO $^{4} \&$ Siska Tridesianti ${ }^{2}$}

\author{
${ }^{1}$ Department of Aquaculture, Faculty of Fisheries and Marine Science, IPB University (Bogor \\ Agricultural University), Bogor, Indonesia \\ ${ }^{2}$ Postgraduate Student of Study Program of Microbiology, Department of Biology, Faculty of \\ Mathematics and Natural Sciences, IPB University (Bogor Agricultural University), Bogor, Indonesia \\ ${ }^{3}$ Shrimp Club Indonesia, Banyuwangi, East Java, Indonesia \\ ${ }^{4}$ Department of Aquatic Resources Management, Faculty of Fisheries and Marine Science, \\ IPB University (Bogor Agricultural University), Bogor, Indonesia
}

Hastuti, Y. P., Fatma, Y. S., Pitoyo, H., Wardiatno, Y. \& Tridesianti, S.: Bacterial and plankton communities in mariculture water sources: a case study in Nampu and Sembukan seawaters, Wonogiri, Indonesia. Nat. Croat. Vol. 30, No. 2, 351-366, 2021, Zagreb.

Seawaters in Indonesia, part of the tropical marine ecosystem, have great microbial and plankton diversity. Seawater is used as a water source for marine aquacultures, such as shrimp, milkfish, lobster, and mud crab. Sustainability of environmental resources for supporting aquaculture activities can be assessed by analyzing the actual conditions of the water source environment, including bacterial and plankton communities. However, the characteristics of bacteria and plankton communities in Indonesian seawaters have not been well documented. In this study, we investigated the bacterial and plankton communities in surface seawater from two coastal areas, i.e. Nampu and Sembukan, Wonogiri regency, Central Java, Indonesia. Bacterial diversity was analyzed using the Illumina-based high throughput sequencing with a primer set targeting the V3-V4 region of the bacterial 16S rRNA gene. Meanwhile, the plankton community (phytoplankton and zooplankton) was calculated and identified using a counting chamber method. Sequencing analysis revealed that the five dominant bacterial phyla in the two seawater samples were similar, consisting of Proteobacteria, Firmicutes, Actinobacteria, Bacteriodetes, and Cyanobacteria. Although the two sites are separated by several kilometres, the distribution of dominant bacterial phyla in both seawater samples is similar. Phytoplankton in Nampu and Sembukan were similarly dominated by Trichodesmium sp., Navicula sp., and Rhabdonema sp. Dominant zooplankton in the two sites were Euterpina, Nauplius, Oithona sp., Oncaea sp., Tigriopus sp., and Gastropoda larvae. The seawater in Nampu and Sembukan is suitable as a water source for aquaculture.

Keywords: bacterial diversity, microbiome, plankton, marine water, tropical seawater

Hastuti, Y. P., Fatma, Y. S., Pitoyo, H., Wardiatno, Y. \& Tridesianti, S.: Bakterijske i planktonske zajednice u marikulturi: studija slučaja u moru područja Nampu i Sembukan, Wonogiri, Indonezija. Nat. Croat. Vol. 30, No. 2, 351-366, 2021, Zagreb.

Morske vode Indonezije dio su tropskog morskog ekosustava i karakterizira ih velika raznolikost mikroorganizama i planktona. Morska voda koristi se za potrebe marikulture, npr. pri uzgoju kozica,

corresponding author; e-mail: yuniha@apps.ipb.ac.id 
mliječne ribe, hlapova te mangrovskog raka. Održivost okolišnih izvora koji se koriste u marikulturi može biti procijenjena analiziranjem stvarnih uvjeta u morskom okolišu, uključujući bakterijske i planktonske zajednice. No karakteristike tih zajednica $\mathrm{u}$ indonezijskim vodama nisu dobro dokumentirane. $\mathrm{U}$ ovom radu istražujemo bakterijske i planktonske zajednice $u$ površinskim vodama dvaju obalnih područja, Nampu i Sembukan, uprava Wonogiri, središnja Java, Indonezija. Raznolikost bakterija analizirana je pomoću brzog Illumina sekvencioniranja s primerom za regiju V3-V4 bakterijske sekvence gena $16 \mathrm{~S}$ rRNA. Osim toga, određena je i izračunata planktonska zajednica (fitoplankton i zooplankton) koristeći metodu komorice za brojanje. Sekvencirajuća analiza pokazala je da je pet dominantnih bakterijskih koljena u dva uzorka morske vode bilo zajedničko, a to su Proteobacteria, Firmicutes, Actinobacteria, Bacteriodetes i Cyanobacteria. Iako su dva uzorkovana područja udaljena nekoliko kilometara, rasprostranjenost dominirajućih bakterijskih koljena u oba uzorka bila je slična. U fitoplanktonu područja Nampu i Sembukan dominirali su Trichodesmium sp., Navicula sp. i Rhabdonema sp. Dominantni zooplankton u oba područja sastojao se od rodova Euterpina, Nauplius, Oithona sp., Oncaea sp., Tigriopus sp. i ličinki Gastropoda. Morska voda područja Nampu i Sembukan prikladna je kao izvor vode za akvakulturu.

Ključne riječi: raznolikost bakterija, mikrobiom, plankton, morska voda, tropska mora

\section{INTRODUCTION}

Water sources play a pivotal role in aquaculture sustainability and waste production. The characteristics of seawater in the natural environment can be used as a reference for water source utilization for aquaculture. Seawater quality is related to the suitability of environmental parameters, such as physical, chemical, and biological characteristics. The biological parameter is one of the important environmental parameters for the dynamics of chemical parameters and biological parameters itself. Microbial diversity in the water environment, a part of the biological parameters, could affect the diversity and abundance of other biological parameters, including plankton (phytoplankton and zooplankton). FENCHEL \& FinLAY (2004) reported that the diversity and dominance of microbes in the water environment could affect the diversity and dominance of plankton inhabiting the area. This phenomenon is related to the production level and the physicochemical dynamics of water influenced by the microbial population and activity. In addition, microbes could be used as a bioindicator of phytoplankton (OkTaviany et al., 2018). Phytoplankton has been widely used as a bioindicator of water quality and productivity and can contribute to the fertility level of the water environment (ODUM, 1993). Phytoplankton requires a variety of nutrients in the water environment for photosynthesis. One of the essential nutrients needed for photosynthesis is nitrogen. Nitrogen in the water environment is available in the form of inorganic nitrogen produced by microbial activity, such as bacteria. Characterizing and identifying the microbes involved in nitrogen cycling, such as nitrifying and denitrifying bacteria, are essential to maintain aquaculture environment stability (HASTUTI et al., 2019). The actual conditions of microbes, both their activity and diversity, in the water environment, could have an influence on aquaculture production (HASTUTI et al., 2018). In general, the diversity of microbes and phytoplankton can be used as bioindicators of water quality in aquaculture environments (CAReghino et al., 2014).

Indonesian seawater area, which is $70 \%$ wider than the land area, has excellent development opportunities in the aquaculture sector. Seawater in Indonesia is frequently used as a water source for aquaculture activities, such as the farming of grouper, shrimp, lobster, crab, sea cucumber, milkfish and other various marine aquatic biota. For aquaculture activities, one of the essential requirements is good 
water quality (including chemical, physical, and biological parameters), which can be used as a reference for subsequent water quality management during the cultivation period (HastuTi et al., 2021). Up to now, there has been little information related to the biological characteristics in Indonesian seawater ecosystems, including bacterial and plankton communities. Not all bacterial and plankton groups are beneficial for a healthy ecosystem in aquaculture ponds. Several microbial and plankton groups are toxic to the aquaculture environment and have an impact on aquaculture sustainability. Hence, bacterial and plankton communities in seawater environments need to be investigated to support sustainable aquaculture.

Wonogiri is one of the regencies in Central Java Province, Indonesia which harbors two coastal areas named Nampu and Sembukan. Seawater environment in Nampu and Sembukan is part of the Indian ocean with base characteristics of coral and sand. Since 2004, some studies in Nampu and Sembukan have observed that these areas are coral-based seas inhabited by lobsters with high economic value (ZAEnUdDin \& Putri, 2017; BENI et al., 2020). Nampu and Sembukan seawater environments have coral and sand bases that allow better growth of crustaceans than in other locations. However, the characteristics of the bacterial and plankton communities in Nampu and Sembukan seawater have not been reported. This present study aimed to identify the diversity and abundance of bacteria and plankton as biological parameters in Nampu and Sembukan seawater environment. These data would be used as a baseline for the utilization of Nampu and Sembukan seawater as the water source for various aquaculture activities.

\section{MATERIALS AND METHODS}

\section{Study area}

Seawater samples were collected on December 2018 in two coastal areas that are more than $10 \mathrm{~km}$ apart, i.e., Nampu (Latitude: 8²'38.17"S, Longitude: $110^{\circ} 54^{\prime} 10.44^{\prime \prime} \mathrm{E}$ ) and Sembukan (Latitude: $8^{\circ} 12^{\prime} 17.39^{\prime \prime} \mathrm{S}$, Longitude: 110 50`38.88”'E), Wonogiri regency, Central Java, the southern coast of Java, Indonesia (Fig. 1). We collected seawater from the euphotic zone, which is sea surface area at a depth of less than 1-5 m, at each sampling site.

\section{Samples collection}

At each sampling site, we sampled $25 \mathrm{~L}$ of marine water in four replicates, then we mixed those water samples to obtain a composite sample. We took $200 \mathrm{~mL}$ of this water composite sample using a sterile bottle for bacterial diversity analysis. Seawater samples collected from Nampu and Sembukan were marked as W.NP and W.SB, respectively.

\section{Extraction of genomic DNA from marine water samples}

Marine water samples from both sites (200 mL per site) were separately filtered through a $0.22 \mu \mathrm{m}$-pore-sized polycarbonate membrane filter (Millipore, Bedford, MA, USA) to capture microbial cells. Whole microbial genomic DNA from marine water samples was extracted using the PowerWater DNA Isolation Kit (MoBio Labo- 

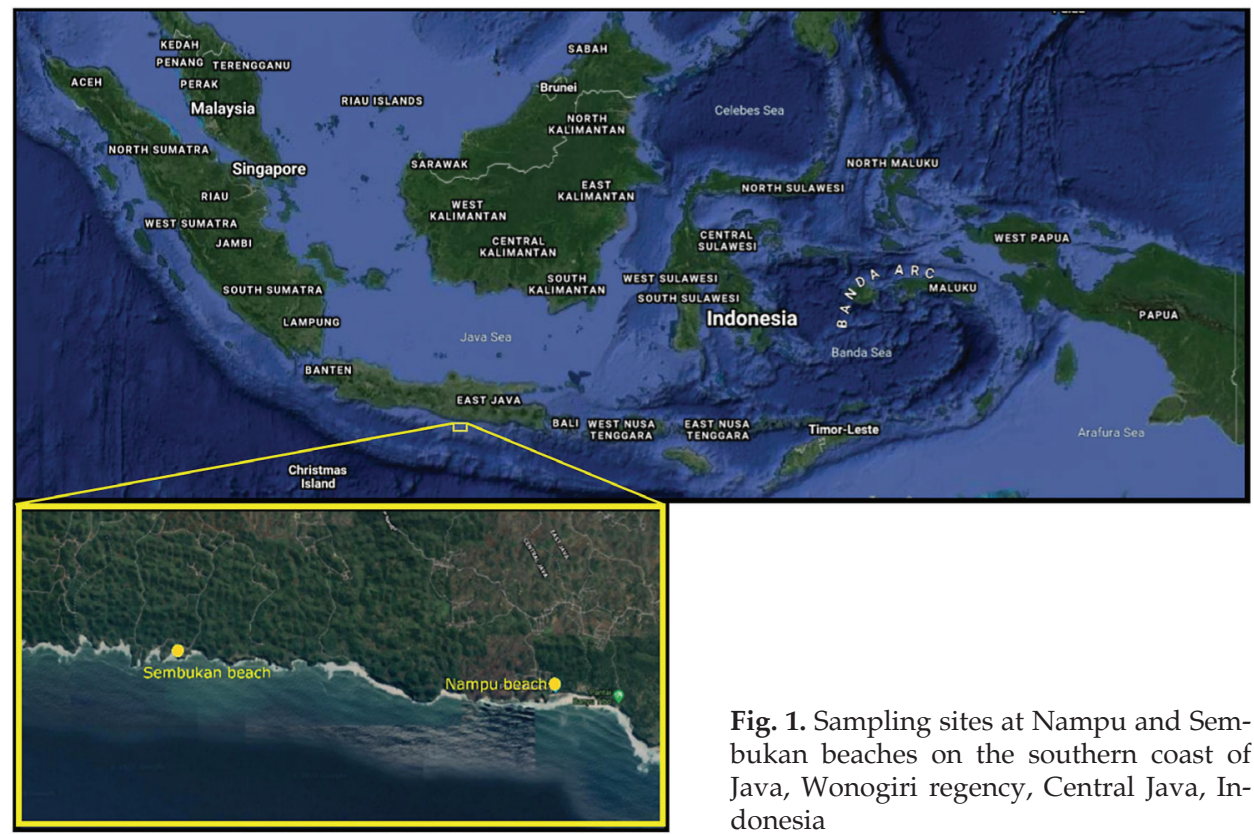

Fig. 1. Sampling sites at Nampu and Sembukan beaches on the southern coast of Java, Wonogiri regency, Central Java, Indonesia

ratories, Carlsbad, CA, USA) according to the manufacturer's manual. DNA concentration and purity were assessed by Nanodrop 2000c (NanoDrop Technologies, Wilmington, DE, USA) and electrophoresis on a $2 \%$ agarose gel.

\section{PCR amplification of bacterial 16S rRNA gene and sequencing}

A universal primer set, 341F (5'-CCTAYGGGRBGCASCAG-3') and 806R (5'-GGACTACNNGGGTATCTAAT-3') added with the Illumina barcodes, was used to amplify the V3-V4 hypervariable region of the bacterial 16S rRNA gene (MUYZER et al., 1993; CAPORASO et al., 2011). For each sample, PCR reactions were performed using Phusion ${ }^{\circledR}$ High-Fidelity PCR Master Mix (New England Biolabs, Ipswich, MA, USA). The PCR reaction mixture consisted of $12.5 \mu \mathrm{L}$ of Phusion 2x Master Mix, 1.25 L of each $10 \mu \mathrm{M}$ forward and reverse primers, $\sim 5 \mu \mathrm{L}$ of the template DNA, $0.75 \mu \mathrm{L}$ of dimethyl sulfoxide (DMSO), and nuclease-free water up to $25 \mu \mathrm{L}$. PCR products were visualized using electrophoresis on $2 \%$ agarose gel. DNA bands between $400-450$ bp were chosen for the subsequent step. PCR products were purified using the Qiagen Gel Extraction Kit (Qiagen, Inc., Valencia, CA, USA). Purified PCR products were used for the library generations performed using NEBNext ${ }^{\circledR}$ Ultra ${ }^{\mathrm{TM}}$ DNA Library Prep Kit (NEB, Ipswich, MA, USA) for the Illumina platform. The libraries were quantified using Qubit and qPCR, then analyzed by Illumina HiSeq 2500 PE250/Ion S5 XL platform (Illumina, Inc., San Diego, CA, USA).

\section{Data processing}

Paired-end reads were assigned according to their unique barcode. The barcode and primer sequences were truncated from the paired-end reads, then merged using 
FLASH v1.2.7 to generate raw tags (MAGOČ \& SAlzberg, 2011). The raw tags' quality was filtered to obtain high-quality clean tags (Bokulich et al., 2013). This step was conducted using the QIIME v1.7.0 under a specific quality-controlled process (CAPORASO et al., 2010). Obtained high-quality reads were compared with the Gold database to detect chimera sequences using the UCHIME algorithm (HAAs et al., 2011; EdGAR et al., 2011). The chimera was removed, and then effective tags were finally generated. Clustering all the effective tags into the operational taxonomic units (OTUs) at $\geq 97 \%$ sequence similarity was performed by UPARSE v7.0.1001 (EDGAR, 2013). The sequence frequently existing in each OTU was used as a representative sequence for subsequent analysis. Species annotation at each taxonomic level was performed for each representative sequence at the threshold of 0.8-1 using Mothur software based on the SILVA database (WANG et al., 2007; QUAST, 2013). The phylogenetic relationship of all representative sequences was assessed by using the MUSCLE program (EDGAR, 2004). OTU abundance information was normalized according to the sample with the least sequence number, then used for alpha diversity analysis. Alpha diversity describes the complexity of bacterial diversity in each sample. Analysis of alpha diversity was carried out using QIIME v1.7.0 and displayed with R software v2.15.3 through 6 indices, such as observed species, Shannon index, Simpson index, Chao1, ACE, and Good's coverage. Chao1 and ACE, the non-parametric estimators, were used to estimate the species richness and indicate the possible total number of bacterial species in a sample (CHAO et al., 1993; CHAO, 1984). Non-parametric richness estimator Chao1 is a statistical estimation of the true species richness community, which includes unobserved species (CHAO, 1984). Good's coverage for the 3\% dissimilarity level was generated with the equation: $1-n / N$, in which $n$ and $N$ represent the number of singletons in the OTUs and the total number of the reads, respectively (GoOD, 1953). The Venn diagram was used in show the OTUs to the samples and specific OTUs in each sample.

\section{Plankton abundance and identification}

Plankton was captured by filtering $25 \mathrm{~L}$ of marine water samples using a 30 $\mu \mathrm{m}$-pore-sized plankton net, then $0.5 \%$ Lugol's iodine was added. Plankton was calculated and identified using the Sedgewick-Rafter counting method under a light microscope with 10x10 magnification. Plankton quantitative analysis was calculated using the Shannon-Wiener formula. Then, we identified phytoplankton and zooplankton according to FukUyo \& BorJa (1991) and Odum (1993).

\section{RESULTS}

\section{Bacterial diversity in Nampu and Sembukan seawater}

On average, 99,198 sequences read were obtained per sample. Alpha diversity measurement of W.NP and W.SB sample is shown in Tab. 1. In each sample, Chao1 and ACE value showed a difference between observed and expected OTU richness. It suggests that a great bacterial diversity was undiscovered in both samples, and more OTUs may exist. The Shannon and Simpson diversity indices revealed that W.NP had a higher bacterial diversity than W.SB. This result was supported by the number 
Tab. 1. The summary of alpha diversity for marine water from Nampu (W.NP) and Sembukan (W.SB)

\begin{tabular}{|c|c|c|c|c|c|c|}
\hline $\begin{array}{c}\text { Sample } \\
\text { name }\end{array}$ & OTUs number & Shannon & Simpson & Chao1 & ACE & $\begin{array}{c}\text { Good's } \\
\text { coverage }\end{array}$ \\
\hline W.NP & 1,932 & 6.725 & 0.923 & $2,032.80$ & $2,040.84$ & 0.997 \\
\hline W.SB & 1,548 & 7.360 & 0.959 & $1,568.64$ & $1,602.13$ & 0.998 \\
\hline
\end{tabular}

of observed species, in which W.NP had more diverse bacteria than that of W.SB. Good's coverage values for W.NP and W.SB were 0.997 and 0.998 , respectively. This value implies that the samples investigated in this study were adequate to evaluate the bacterial community in each seawater sample. Rarefaction curve represents a common technique for examining whether the achieved species richness for a sequencing experiment is suitable for subsequent analysis or higher sequencing depth is needed to achieve more expected species richness. The rarefaction curves were constructed by plotting the number of OTUs as a function of the number of sequences and determining a saturation point. The rarefaction curve in this study confirms that the obtained sequence coverage of each sample is high enough to perform each possible diversity analysis (Fig. 2). A Venn diagram revealed that W.NP and W.SB contained 754 and 370 OTUs, respectively, which were specific to the given sample, and had 1,178 OTUs in common (Fig. 3).

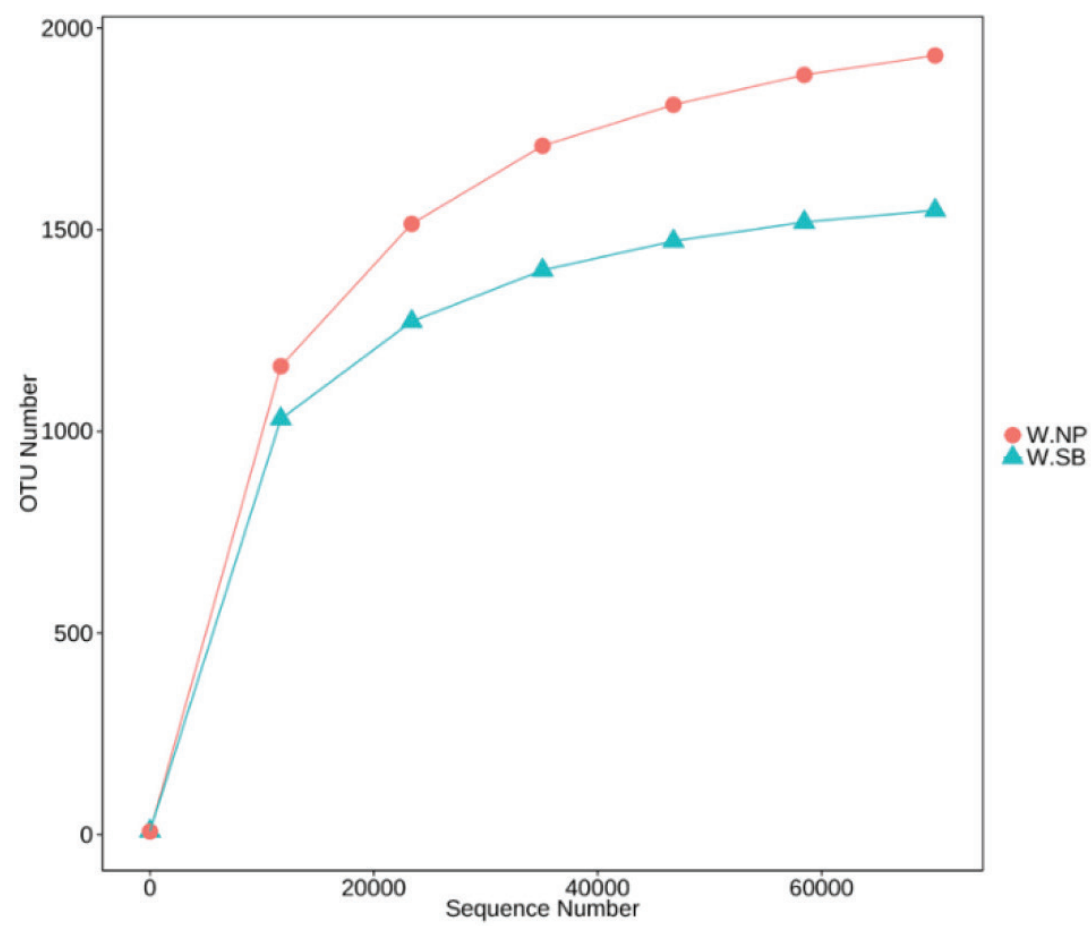

Fig. 2. The rarefaction curves of marine water from Nampu (W.NP) and Sembukan (W.SB) constructed by counting the number of OTUs along with increasing in the number of sequence reads. 


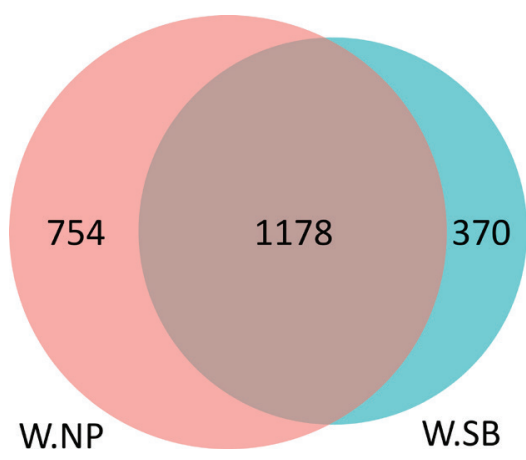

Fig. 3. Venn diagram of bacterial diversity of marine water sample from Nampu (W.NP) and Sembukan (W.SB).

\section{Phylogenetic composition of bacteria}

In this study, we found five dominant bacterial phyla with more than $1 \%$ in relative abundance that existed across all seawater samples, including Proteobacteria, Firmicutes, Actinobacteria, Bacteriodetes, and Cyanobacteria. Proteobacteria was the most dominant phylum in W.NP and W.SB, accounting for $59.8 \%$ and $69.8 \%$ of the total sequences, respectively (Fig. 4a). Proteobacteria consisted of Gammaproteobacteria (W.NP: 45.0\% vs. W.SB: 43.0\%), Alphaproteobacteria (W.NP: 7.9\% vs. W.SB: 2.1\%), Betaproteobacteria (W.NP: $6.0 \%$ vs. W.SB: $2.8 \%$ ), Deltaproteobacteria (W.NP: $0.5 \%$ vs. W.SB: $0.8 \%$ ), and Epsilonproteobacteria (W.NP: $0.2 \%$ vs. W.SB: $0.1 \%$ ). The result showed slight discrepancies in the bacterial composition of the other phyla between these two samples. In W.NP, Firmicutes (20.3\%), Actinobacteria $(6.24 \%)$, Bacteriodetes (5.94\%) and Cyanobacteria (3.95\%) dominated the bacterial community. Meanwhile, W.SB was dominated by Actinobacteria $(12.32 \%)$, followed by Firmicutes (5.78\%), Bacteriodetes (5.1\%) and Cyanobacteria $(2.3 \%)$. Other bacterial phyla were present with a lower proportion (0.1-1\%) in W.NP and W.SB, such as Tenericutes (W.NP: $0.8 \%$ vs. W.SB: $0.7 \%$ ), Chloroflexi (W.NP: $0.2 \%$ vs. W.SB: $0.7 \%$ ), Acidobacteria (W.NP: $0.7 \%$ vs. W.SB: 0.7\%), Fusobacteria (W.NP: 0.7\% vs. W.SB: $0.1 \%$ ), and Verrucomicrobia (W.NP: $0.1 \%$ vs. W.SB: 0.3\%). In general, both seawater samples had relatively similar composition of dominant bacterial phyla.

We also observed the bacterial sequence reads to family and genus level (Fig. 4b, 4c). Different distribution of bacterial communities in the family and genus level was found in W.NP and W.SB seawater. In W.NP, we observed dominant families, in decreasing order of abundance, as follows: Xanthomonadaceae (26.8\%), Enterobacteriaceae $(10.0 \%)$, Ruminococcaceae $(5.7 \%)$, Streptococcaceae $(4.9 \%)$, and Lachnospiraceae $(4.1 \%)$. Meanwhile, W.SB was dominated by Solimonadaceae $(18.6 \%)$, followed by Rhodobacteraceae (5.3\%), Alcanivoracaceae (4.6\%), Erythrobacteraceae $(4.0 \%)$, and Enterobacteriaceae $(3.6 \%)$. By contrast, we found only a small share of Xanthomonadaceae $(1.3 \%)$, which was a common family in W.NP, in the W.SB sample (Fig. $4 \mathrm{~b})$. At the genus level, the bacterial community in W.NP seawater was dominated by Stenotrophomonas (26.3\%), Escherichia-Shigella (4.3\%), Faecalibacterium $(3.4 \%)$, Delftia $(2.9 \%)$, and Streptococcus $(2.6 \%)$. On the other hand, W.SB was dominated by Alcanivorax $(4.5 \%)$, followed by Erythrobacter $(3.8 \%)$, Nautella $(2.4 \%)$, Escherichia-Shigella (1.9\%), and Stenotrophomonas (0.9\%) (Fig. 4c). 
(a)

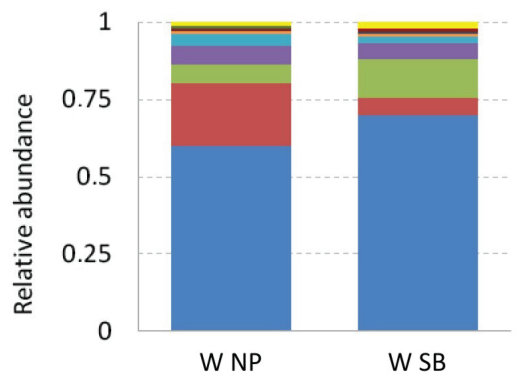

(b)

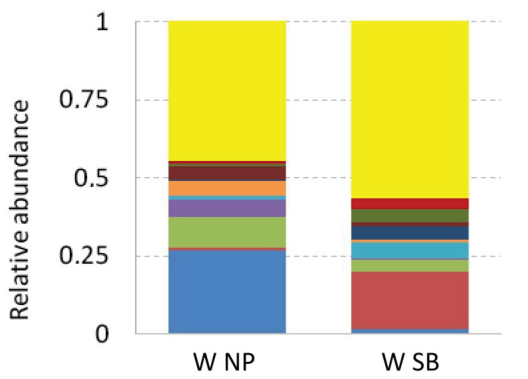

(c)

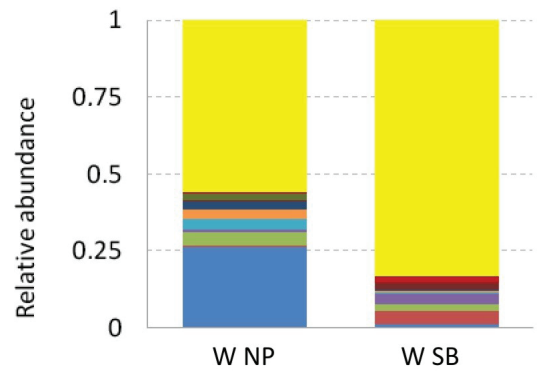

Others

- Verrucomicrobia

- Fusobacteria

- Acidobacteria

- Chloroflexi

- Tenericutes

- Cyanobacteria

- Bacteroidetes

- Actinobacteria

- Firmicutes

Others

- Moraxellaceae

- Erythrobacteraceae

- Lachnospiraceae

- Alcanivoracaceae

- Streptococcaceae

- Rhodobacteraceae

- Ruminococcaceae

- Enterobacteriaceae

- Solimonadaceae

Xanthomonadaceae

Others

- Acinetobacter

- Lactococcus

- Nautella

- Streptococcus

- Delftia

- Faecalibacterium

- Erythrobacter

- Escherichia-Shigella

- Alcanivorax

Fig. 4. Bacterial community composition of marine water samples from Nampu (W.NP) and Sembukan (W.SP) corresponds to the dominantly appearing bacterial taxa on phylum (a), family (b), and genus (c) level of taxonomy. Only the top ten dominant taxa were selected.

\section{Plankton community in Nampu and Sembukan seawater}

We observed the abundance and diversity of phytoplankton and zooplankton in Nampu and Sembukan seawater. The result showed that the abundances of phytoplankton in W.NP and W.SB were slightly different. Phytoplankton in W.SB is more numerous than in W.NP (Tab. 2). The Shannon-Wiener diversity analysis showed that the number of taxa, abundance, diversity, and similarity of phytoplankton in W.NP were similar to those in W.SB (Fig. 5). Dominant phytoplankton groups consisted of Trichodesmium sp., Navicula sp., and Rhabdonema sp. (Tab. 2).

The diversity and abundance of zooplankton in Nampu and Sembukan seawater were more different. Zooplankton community in W.NP and W.SB were dominated by Euterpina sp., Nauplius, Oithona sp., Oncaea sp., Tigriopus sp., and Gastropoda larvae (Tab. 3). The number of taxa and abundance of zooplankton in W.NP were higher than in W.SB, while diversity and similarity of zooplankton in W.NP were lower than that in W.SB. Dominance index of zooplankton in both sampling sites have similar values, reaching 0 (Fig. 6). 
Tab. 2. Abundance of phytoplankton in the marine water environment of Nampu (W.NP) and Sembukan (W.SB)

\begin{tabular}{|c|c|c|c|}
\hline Family & Species & W.NP & W.SB \\
\hline \multirow{7}{*}{ Cyanophyceae } & Trichodesmium sp. & $2,087,072$ & $2,749,623$ \\
\hline & Asterionella sp. & - & 29,159 \\
\hline & Bacillaria sp. & - & 8,696 \\
\hline & Biddulphia sp. & 29,217 & 27,072 \\
\hline & Campylodiscus sp. & - & 580 \\
\hline & Cocconeis sp. & 696 & 754 \\
\hline & Coscinodiscus sp. & 6,145 & 4,928 \\
\hline \multirow{13}{*}{ Bacillariophyceae } & Cymbella sp. & 696 & - \\
\hline & Eunotia sp. & 1,275 & 580 \\
\hline & Fragilaria sp. & 696 & 1,507 \\
\hline & Grammatophora sp. & 7,652 & - \\
\hline & Licmophora sp. & 10,087 & 8,116 \\
\hline & Melosira sp. & 696 & - \\
\hline & Navicula sp. & 105,739 & 121,217 \\
\hline & Nitzschia sp & 5,333 & 1,913 \\
\hline & Pleurosigma sp. & 696 & 1,507 \\
\hline & Rhabdonema sp. & 145,159 & 182,783 \\
\hline & Rhizosolenia sp. & 2,667 & 1,159 \\
\hline & Synedra sp. & - & 754 \\
\hline & Triceratium sp. & 4,870 & 28,464 \\
\hline Dinophyceae & Pyrocystis sp. & - & - \\
\hline
\end{tabular}

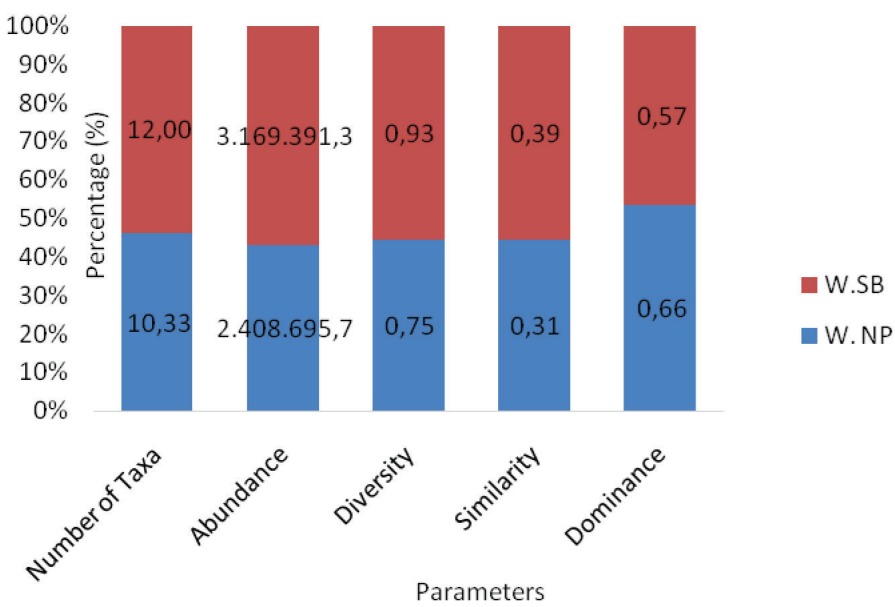

Fig. 5. The number of taxa, abundance, diversity, similarity, and dominancy of phytoplankton existed in marine water environment of Nampu and Sembukan 
Tab. 3. Abundance of phytoplankton in the marine water environment of Nampu (W.NP) and Sembukan (W.SB)

\begin{tabular}{|c|c|c|c|}
\hline Group & Species & W.NP & W.SB \\
\hline \multirow{3}{*}{ Protozoa } & Favella sp. & - & 1,043 \\
\hline \multirow{5}{*}{ Tretomphalus sp. } & Globorotalia sp. & 1,913 & 696 \\
\cline { 2 - 4 } & Conchoecia sp. & 377 & 0 \\
\cline { 2 - 4 } & Euterpina sp. & 18,783 & 16,870 \\
\cline { 2 - 4 } & Microsetella sp. & - & 0 \\
\cline { 2 - 4 } & Nauplius (stadia) & 8,812 & 9,217 \\
\cline { 2 - 4 } & Oithona sp. & 1,710 & 1,043 \\
\cline { 2 - 4 } & Oncaea sp. & 4,145 & 0 \\
\cline { 2 - 4 } & Paracalanus sp. & - & 2,435 \\
\cline { 2 - 4 } & Tigriopus sp. & 4,464 & 3,130 \\
\cline { 2 - 4 } & Nematoda Worm $(\mathrm{sp} 1)$ & 580 & 0 \\
\cline { 2 - 4 } & Larva Gastropoda $(\mathrm{sp} 1)$ & 2,464 & 0 \\
\hline
\end{tabular}

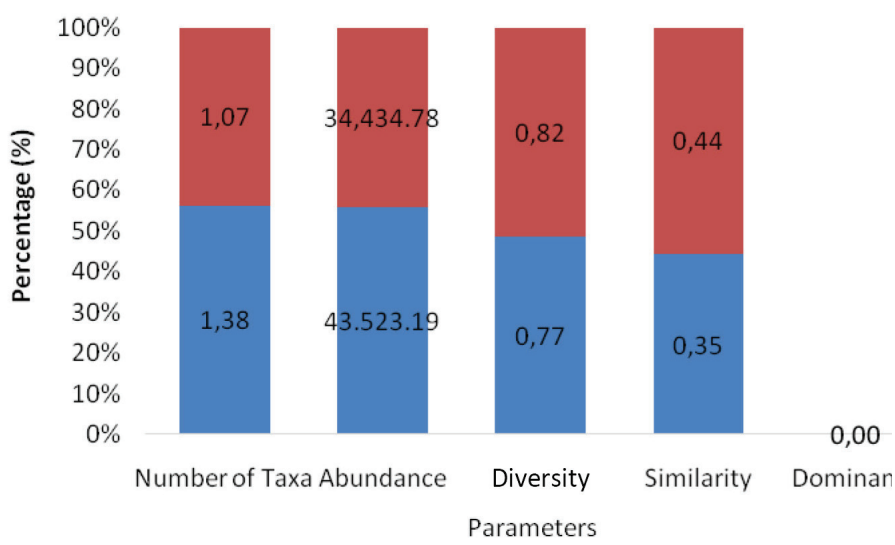

Fig. 6. The number of taxa, abundance, diversity, and similarity of zooplankton in marine water environment of Nampu and Sembukan

\section{DISCUSSION}

We investigated the bacterial and plankton community composition of two seawater samples, collected from Nampu and Sembukan. Nampu and Sembukan are more than $10 \mathrm{~km}$ apart and located in the same regency, i.e., Wonogiri regency, Central Java. The results showed that these two sites seemed to be similar in the diversity and composition of the dominant bacterial phyla (Tab. 1, Fig. 4). This might be caused by the similar marine environment properties in the two sites. These two locations were considered to have the same water mass and physicochemical properties. Our finding agrees with other metagenomic studies of marine bacteria, in which microbial composition could be relatively consistent in similar marine environments separated by long distances (INAGAKi et al., 2006; AGOGUÉ et al., 2011; WALSH et al., 2015). Seawater samples taken apart horizontally at a distance of hundreds to thousands of kilome- 
ters within a single water mass had a similar bacterial community composition to each other, yet they vertically differed with water depth (AGOGUÉ et al., 2011; WALSH et al., 2015). On the other hand, adjacent marine water masses with different environmental conditions have distinct microbial communities (AGOGUÉ et al., 2011; HAMDAN et al., 2013). Previous investigations reported that microbial community composition varies from one marine environment to another (Delong et al., 2006; Zinger et al., 2011; Hamdan et al., 2013).

The microbial community regulates many processes in the ecosystems, including nutrient transformation and organic matter decomposition. Bacteria affiliated to distinct groups can exhibit different degrees of activity in a given ecosystem. Detection of the dominant bacterial group may be crucial to understanding their function in the biogeochemical cycle (AzAm \& Worden, 2004; Martiny et al., 2006). Cottrell \& KirchMAN (2000) reported that major phylogenetic bacterial groups utilize different dissolved organic matter (DOM), yet it often does not correlate with their relative abundance in the estuarian and coastal environment. In this study, analysis of the affiliation of OTUs showed that Gammaproteobacteria was a prevalent member in both seawater samples (W.NP $=45.0 \%$ vs. W.SB $=43.0 \%$ ). Alphaproteobacteria and Betaproteobaceria were present in lower proportions (Fig. 4A). Our result is in line with previous investigations that revealed that Gammaproteobacteria and Alphaproteobacteria were the common members of sea surface microbiota in the North Pacific Subtropical Gyre (Delong et al., 2006) and the Red Sea (QIAN et al., 2011). Alphaproteobacteria, Bacterioidetes, and Gammaproteobacteria were the most dominant phyla in Arctic surface water, and Firmicutes exist on average 5\% in Pacific and Atlantic water (Hamdan et al., 2013). Alphaproteobacteria, Flavobacteria, and Cyanobacteria dominated pelagic marine microbiota. Higher proportions of Flavobacteria and lower proportions of Alphaproteobacteria and Cyanobacteria were detected in coastal marine than in open ocean surface water, yet bacterial communities in these two sites related to each other. Generally, Gammaproteobacteria dominated in pelagic and benthic seawater (ZINGER et al., 2011).

Proteobacteria has the largest and phenotypically most diverse phylogenetic lineage. Gammaproteobacteria is the largest group, consisting of the photosynthetic purple sulfur bacteria (Kersters et al., 2006). This group might play an essential role in the photosynthetic process in both marine environments in this study. Gammaproteobacteria is a gram-negative bacterial group dominated by Alkalimonas, Litorivivens, Pseudomonas, and Marinicella (William et al., 2010). Alphaproteobacteria usually dominate in amino acid consumption. However, no phylogenetic group dominates all DOM consumption. It suggests that diverse groups' contributions are essential for the complete degradation of complex DOM in the oceans (CotTrell \& Kirchman, 2000).

In this study, we found Cyanobacteria to be one of the most abundant phyla with a lower proportion than Proteobacteria (Fig. 4A). In contrast to this study, QIAN et al. (2011) reported that Cyanobacteria dominated the bacterial community in the upper water column, whereas Proteobacteria had a large proportion in the deeper water column. Cyanobacteria is capable of photosynthesis and nitrogen fixation in the presence of light and oxygen, causing the dominance of performing this group in the euphotic zone (20 and $50 \mathrm{~m}$ ). Cyanobacteria were more abundant in open ocean surface waters than in coastal waters (Zinger et al., 2011). Delong et al., (2006) reported 
that the photic zone $(10,70$, and $130 \mathrm{~m}$ depth) contained the DNA sequences associated with photosynthesis, chlorophyll and porphyrin metabolism, the metabolism of amino sugars, purine propanoate and vitamin B6, and type III secretion systems. The high abundance of Cyanobacteria in the environment can affect the concentration of inorganic nitrogen because of its nitrogen fixation and photosynthesis ability.

We took surface seawater samples in two coastal areas which are $1 \mathrm{~km}$ apart from the land. Coastal water shares a higher proportion of OTU with benthic communities. The differences in microbial communities in coastal water might be resulted from benthic taxa that were resuspended in the water column through upwelling current and storms, the influence of land which provides higher freshwater, nutrient and organic matter, and sediment (ZINGER et al., 2011). Our results showed a high proportion of Stenotrophomonas (Xanthobacteriaceae, Gammaproteobacteria), EscherichiaShigella (Enterobacteriaceae, Gammaproteobacteria), Faecalibacterium (Clostridia, Firmicutes), Delftia (Commonadaceae, Betaproteobacteria), and Streptococcus (Streptococcaceae, Firmicutes) in W.NP (Fig. 3C). Meanwhile, the W.SB microbiota was dominated by Alcanivorax (Alcanivoracacceae, Gammaproteobacteria), followed by Erythrobacter (Erytrobacteraceae, Alphaproteobacteria), Nautella (Rhodobacteraceae, Alphaproteobacteria), Escherichia-Shigella (Enterobacteriaceae, Gammaproteobacteria), and Stenotrophomonas (Streptococcaceae, Firmicutes) (Fig. 4C). This result is in line with a previous report, which observed Firmicutes (Bacilli and Clostridia) in a higher proportion in coastal sediment (ZINGER et al., 2011). Bacilli and Clostridia have been previously reported as indicators of human fecal contaminations in watersheds (Wu et al., 2010), as are Escherichia-Shigella (Enterobacteria) and other common taxa in soils (JANSSEN, 2006). The existence of these taxa in coastal water observed in our study might be from the terrestrial environment. As suggested by Zinger et al. (2011), these groups are almost absent in marine ecosystems and they might not be adapted to aquatic conditions and the presence of dissolved oxygen, where many members of these clades are anaerobes. Coastal ecosystems are subjected to increasing pollution and habitat loss (HALPERN et al., 2008). Slight differences in bacterial and plankton communities between those two areas in this study were presumably influenced by household and industry pollution. Moreover, our seawater sample might be affected by terrestrial run-off and nutrient-rich up-welling zones, as reported in a previous report by D'HondT et al. (2009).

Microbial community structure in the marine water can be influenced by physical parameters, including temperature and salinity, resource availability, and selective loss factors (grazing and viral lysis). Potential oceanographic barriers, such as temperature, salinity, and density, separate the water masses and their bacterial communities. Spatial distribution of the bacterial richness and evenness might occur according to water masses, where bacterial assemblages are clearly clustered according to the distinct water masses. Specific environmental properties, including water mass identity and latitude, dissolved organic carbon (DOC), $\mathrm{O}_{2}$, and apparent oxygen utilization (AOU), determine the bacterial community composition in the North Atlantic (AgOGué et al., 2011). Water mass also plays an important role in the microbial distribution in the Arctic Ocean (Galand et al., 2009). The salinity and density were the principal structuring elements on the bacterial community in the pelagic zone, yet distance was not an essential structuring element (HAMDAN et al., 2013).

We collected seawater samples from the photic zone in coastal areas. In the photic zone, species distribution in the water column was influenced by the gradient of light 
quality and intensity, temperature, macronutrient, and trace metal concentration (Hochachka et al., 1984). High density and diversity of microbiota in the upper zone is caused by higher DO, temperature, fluorescence intensity, and moderate salinity, in contrast to the lower zone, which has greater salinity and lower light intensity (QIAN et al., 2011). It differs from the greater depths, which are influenced by light disappearances, low temperature, high hydrostatic pressure, low energy supplies (Delong et al., 2006). The abundance of microbial communities in marine environments differs according to the depth, in which there is vertical distribution influenced by environmental factors, such as light intensity, DO, temperature, nutrient concentration, hydrostatic pressure and geochemical factors (QIAN et al., 2011). QIAN et al. (2011) suggested that the samples collected from surface water may be affected by frequent changes in various factors, where the levels of diversity and density of microbiota at different sampling times and sites may also be different. The problems could lead to inaccurate conclusions regarding the microbial composition in these environments. Further experiments are needed to understand the microbial community structure and its function in marine water.

Microbial diversity in an aquatic environment could affect the diversity and dominance of phytoplankton and zooplankton in the ecosystem. There is a potential interaction between primary producers and bacteria that has an impact on the stability, physiology, and abundance of both communities. It can affect environmental quality and aquaculture sustainability. It could affect chemical parameters and the diversity in environment, which could influence the subsequent food chain (AmIN et al., 2015). Seawater in Wonogiri (Nampu and Sembukan) has relatively low phytoplankton diversity (Fig. 5). Trichodesmium, a member of the Cyanipiceae groups that have nitrogen fixation ability, was found in the two areas. The high ability of nitrogen fixation in the aquaculture water source environment can lead to algal bloom and abundance of inorganic nitrogen. The high abundance of Trichodesmium in Nampu seawater was also accompanied by the high abundance of Stenotrophomonas (Tab. 2). Genus Stenotrophomonas is one of the endemic bacteria in seawater, which can convert nitrogen into free $\mathrm{N}_{2}$ through denitrification. In addition, the high abundance of Trichodesmium group was not to be a problem when associated with the high diversity of zooplankton. Based on the characteristics of plankton community, zooplankton groups in the two sites had almost the same dynamics and types (Tab. 3; Fig. 6). The zooplankton group was more diverse than the phytoplankton group. The zooplankton mostly obtained in Nampu and Sembukan waters consists of Euterpina, Nauplius, Oithona sp., Oncaea sp., Tigriopus sp., and Gastropoda sp. larvae (Tab. 3).

\section{CONCLUSIONS}

The bacterial composition and diversity in Nampu and Sembukan seawaters that are more than $10 \mathrm{~km}$ apart are similar. The five dominant bacterial phyla in each site were similar, and consisted of Proteobacteria, Firmicutes, Actinobacteria, Bacteriodetes, and Cyanobacteria. Diversity, abundance, and similarity of phytoplankton in Nampu and Sembukan are dominated by Tricodesmium sp., Navicula sp., and Rhabdonema sp. In aquaculture application, Nampu and Sembukan seawater could be used as cultivation water sources due to its relatively high diversity of bacteria and plankton. However, it is necessary to do the treatment first because of the dominance of Trichodesmium sp. and Cyanobacteria in the water environment. Trichodesmium sp. 
is a Cyanophyta group with a high ability to photosynthesize and fix nitrogen, which causes algal bloom and abundant nitrogen waste if it is not appropriately managed. Our study indicates that bacterial and phytoplankton communities are almost similar in horizontally identical sites in a distance of thousands of kilometers apart, as these two locations are considered to have the same water mass and physicochemical properties.

\section{ACKNOWLEDGEMENTS}

We thank the Marine and Fisheries Service of Wonogiri regency, the lobster fishermen of the Wonogiri regency, and the Ministry of Marine Affairs and Fisheries Republic of Indonesia for supporting this study.

Received October 29, 2019

\section{REFERENCES}

Agoguè, H., Lamy, D., Neal, P. R., Sogin, M. L. \& Herdnel, G. J., 2011: Water mass-specificity of bacterial communities in the North Atlantic revealed by massively parallel sequencing. Molecular Ecology 20, 258-274.

Amin, S. A., Hmelo, L. R., Durham, B. P., Carlson, L. T., Heal, K. R., Morales, R. L., Berthiausme, C. T., Parker, M. S., Djunaedi, B., Ingalls, A. E., Parsek, M. R., Moran, M. A. \& Armbust, E. V., 2015: Interaction and signaling between a cosmopolitan phytoplankton and associated bacteria. Nature 522, 98-101.

AzAm, F. \& Worden, A. Z., 2004: Microbes, molecules, and marine ecosystems. Science 303, 1622-1624.

Beni, Zairion \& Wardiatno, Y., 2020: Biological aspect of double-spined rock lobster (Panulirus penicillatus) in Wonogiri Regency waters, Central Java, Indonesia. IOP Conference Series: Earth and Environmental Science 420, 012006.

Bokulich, N. A., Subramanian, S., Faith, J. J., Gevers, D., Gordon, J. I., Knight, R., Mills, D. A. \& CAPORASO, J. G., 2013: Quality-filtering vastly improves diversity estimates from Illumina amplicon sequencing. Nature Methods 10,57-59.

Caporaso, J. G., Kuczynski, J., Stombaugh, J. et al., 2010: QIIME allows analysis of high-throughput community sequencing data. Nature Methods 7, 335-336.

Caporaso, J. G., Lauber, C. L., Walters, W. A., Berg-Lyons, D., Lozupone, C. A., Turnbaugh, P. J., Fierer, N., \& KNIGHT, R. 2011: Global patterns of 16 S rRNA diversity at a depth of millions of sequences per sample. Proceedings of the National Academy of Sciences of the United States of America 108, 4516-4522.

ChaO, A., 1984: Nonparametric estimation of the number of classes in a population. Scandinavian Journal of Statistic 11, 265-270.

ChaO, A., MA, M. C. \& YAnG, M. C. K., 1993: Stopping rules and estimation for recapture debugging with unequal failure rates. Biometrika 80, 193-201.

Careghino, R., Boix, D., Cauchie, H. M., Martens, K. \& Oertli, B., 2014: The ecological role of ponds in a changing world. Hydrobiologia 723, 1-6.

Cottrell, M. T. \& Kirchman, D. L., 2000: Natural assemblages of marine Proteobacteria and members of the Cytophaga-Flavobacter cluster consuming low- and high-molecular-weight dissolved organic matter. Applied and Environmental Microbiology 66, 1692-1697.

Delong, E. F., Preston, C. M., Mincer, T., Rich, V., Hallam, S. J, Frigaard, N.-U. Martinez, A., Sullivan, M. B., Edwards, R., Brito, B. R., Chisholm, S. W., \& Karl, D. M., 2006: Community genomics among stratified microbial assemblages in the ocean's interior. Science 311, 496-503.

D’Hondt, S., Spivack, A., Pockalny, R., Ferdleman, T., Fischer, J. P., Kallmeyer, J., Abrams, L. J., Smitha, D. C., Graham, D., Hasiuk, F., Schrum, H., \& Stancine, A. M., 2009: Subseafloor sedimentary life in the South Pacific Gyre. Proceedings of the National Academy of Sciences USA 106, 11651-11656. 
EDGAR, R. C., 2004: MUSCLE: multiple sequence alignment with high accuracy and high throughput. Nucleic Acids Research 32, 1792-1797.

Edgar, R. C., Haas, B. J., Clemente, J. C., Quince, C. \& Knight, R., 2011: UCHIME improves sensitivity and speed of chimera detection. Bioinformatics 27, 2194-2200.

EDGAR, R. C., 2013: UPARSE: highly accurate OTU sequences from microbial amplicon reads. Nature Methods 10, 996-998.

Fenchel, T. \& FinlaY, B. J., 2004: The ubiquity of small species: patterns of local and global diversity. BioScience 54, 777-784.

Fukuyo, Y. \& Borja. V. M., 1991: Marine Dinoflagellates in the Philippines. Asian Natural Science Centre, Tokyo.

Galand, P. E., Casamayor, E. O., Kirchman, D. L. \& Lovejoy, C., 2009: Ecology of the rare microbial biosphere of the Arctic Ocean. Proceedings of the National Academy of Sciences USA 106, 2242722432.

Good, I. J., 1953: The population frequencies of species and the estimation of population parameters. Biometrika 40, 237-264.

Haas, B. J., Gevers, D., Earl, A. M., Feldgarden, M., Ward, D. V. Giannoukos, G., Ciulla, D. Tabbaa, D., Highlander, S. K., Sodergren, E., Methè, B. Desantis, T. Z., The Human Microbiome Consortium, Petrosino, J. F., Knight, R. \& Birren, B. W., 2011: Chimeric 16S rRNA sequence formation and detection in Sanger and 454-pyrosequenced PCR amplicons. Genome research 21, 494-504.

Halpern, B. S., Walbridge, S., Selkoe, K. A., Kappel, C. V., Migheli, F., D’agrosa, C. Bruno, J. F., Casey, K. S., Ebert, C., Fox, H. E., Fujita, R., Heinemann, D., Lenihan, H. S., Madin, E. M. P., Perry, M. T., Selig, E. R., Spalding, M., Steneck, R. \& Watson, R., 2008: A global map of human impact on marine ecosystems. Science 319, 948-952.

Hamdan, L. J., Coffin, R. B., Sikaroodi, M., Greinert, J., Treude, T. \& Gillevet, P. M., 2013: Ocean currents shape the microbiome of Arctic marine sediments. International Society for Microbial Ecology Journal 7, 685-696.

Hastuti, Y. P., Rusmana, I., Nirmala, K., Affandi, R. \& Tridesianti, S., 2019: Short comunication: identification and characterization of nitrifying bacteria in mud crab Scylla serrata recirculation aquaculture system by $16 \mathrm{~S}$ rRNA sequencing. Biodiversitas 20, 1339-1343.

Hastuti, Y. P., Fatma, Y. S., Pitoyo, H., Nurussalam, W. \& Ruhyana, J., 2021: Assessment of total bacterial diversity in whiteleg shrimps and its aquaculture environment in Pangkajene and Banyuwangi, Indonesia. Asia Pacific Journal of Molecular Biology and Biotechnology 26-37. 10.35118/АРјмвв.2021.029.3.04.

Hastuti, Y. P., Nirmala, K., Merani, D. \& Tridesianti, S., 2018: Actual activity of nitrifying bacteria in culture of mud crab Scylla serrata under recirculating system with various light treatments' AACL Bioflux 11, 1476-1485.

Носнаснка, P. W. \& Somero, G. N., 1984: Biochemical Adaptation. Princeton University Press, Princeton.

Inagaki, F., Nunoura, T., Nakagawa, S., Teske, A., Lever, M., Lauer, A., Suzuki, M., Takai, K., Delwiche, M., Colwell, F. S., Nealson, K. H., Horikoshi, K., D’Hondt, S. \& Jørgensen, B. B., 2006: Biogeographical distribution and diversity of microbes in methane hydrate-bearing deep marine sediments on the Pacific Ocean Margin. Proceedings of the National Academy of Sciences USA 103, 2815-2820.

JANSSEN, P. H., 2006: Identifying the dominant soil bacterial taxa in libraries of $16 \mathrm{~S}$ rRNA and $16 \mathrm{~S}$ rRNA genes. Applied and Environmental Microbiology 72, 1719-1728.

Kersters, K., De Vos, P., Gillis, M., Swings, J., Vandamme, P. \& Stackebrandt, E., 2006: Introduction to the Proteobacteria. Springer, New York.

Magoč, T. \& SAlzberG, S. L., 2011: FLASH: fast length adjustment of short reads to improve genome assemblies. Bioinformatics 27, 2957-2963.

Martiny, J. B. H., Bohannan, B. J. M., Brown, J. H., Colwell, R. K., Fuhrman, J. A., Green, J. L. Horner-Devine, M. C. Kane, M., Krumins, J. A., Kuske, C. R., Morin, P. J., Naeem, S., Øvre̊̊s, L., Reysenbach, A.-L., Smith, V. H. \& Staley, J. T., 2006: Microbial biogeography: putting microorganisms on the map. Nature Reviews Microbiology 4, 102-112.

Muyzer, G., De WaAl, E. C. \& Uitterlinden, A. G., 1993: Profiling of complex microbial populations by denaturing gradient gel electrophoresis analysis of polymerase chain reaction-amplified genes coding for 16S rRNA. Applied and Environmental Microbiology 59, 695-700. 
Odum, E. P., 1993: Fundamental of Ecology. Gadjah Mada University Press, Yogyakarta.

Oktaviany, N. A., Matsugami, A., Malay, A. D., Hayashi, F., Kaplan, D. L. \& Numata, K., 2018: Conformation and dinamics of soluble repetitive domain elucidates the initial b-sheet formation of spider silk. Nature Communication 9, 2121.

Qian, P.Y., Wang, Y., Lee, O. O., Lau, S. C. K., Yang, J., Lafi, F. F., Al-Suwailem, A. \& Wong, T. Y. H., 2011: Vertical stratification of microbial communities in the Red Sea revealed by $16 \mathrm{~S}$ rDNA pyrosequencing. International Society for Microbial Ecology Journal 5, 507-518.

Quast, C., Pruesse, E., Yilmaz, P., Gerken, J., Schweer, T., Yarza, P., Peplies, J., \& Glockner, F. O., 2013: The SILVA ribosomal RNA gene database project: improved data processing and web-based tools. Nucleic Acids Research 41, 590-596.

Walsh, E. A., Smith, D. C., Sogin, M. L. \& D’Hondt, S. L., 2015: Bacterial and archaeal biogeography of the deep chlorophyll maximum in the South Pacific Gyre. Aquatic Microbial Ecology 75, 1-13.

Wang, Q., Garrity, G. M., Tiedje, J. M. \& Cole, J. R., 2007: Naive Bayesian classifier for rapid assignment of rRNA sequences into the new bacterial taxonomy. Applied and Environmental Microbiology $73,5261-5267$.

William, G. R., Tarpy, D. R., Vanengelsdrop, D., Chauzat, M.-P., Cox-Foster, D. L., Delaplane, K. S., Neumann, P., Pettis, J. S., Rogers, R. E. L. \& Shutler, D., 2010: Colony collapse disorder in context. Bioessays 32, 845-846.

Wu, C. H., Sercu, B., Van De Werfhorst, L. C., Wong, J., Desantis, T. Z., Brodie, E. L., Hazen, T. C., Holden, P. A. \& ANDersen, G. L., 2010: Characterisation of coastal urban watershed bacterial communities leads to alternative community-based indicators. PLoS One 5, 1-11.

Zaenuddin, M. \& Putri, D. A. D. 2017: Size composition of lobster (Panulirus penicillatus) in Wonogiri waters, Central Java. Indonesian Journal of Fisheries Science and Technology (IJFST) 12, 109-115.

Zinger, L., Amaral-Zettler, L. A., Furhman, J. A., Horner-Devine, M. C., Huse, S. M., Welch, D. B. M., Martiny, J. B. H., Sogin, M., Boetius, A. \& Ramette, A., 2011: Global patterns of bacterial beta-diversity in seafloor and seawater ecosystems. PLoS One 6, e24570. 